\title{
China's economic expansion and the 'sustainability of sustainability': a Žižekian-Lacanian view
}

\section{A expansão econômica da China e a sustentabilidade: uma visão a partir de Lacan e Žižek}

Antonio Gelis Filho ${ }^{1}$

\begin{abstract}
The aim of this paper is to present a Žižekian-Lacanian interpretation of an interesting socio-economic triangle that has so far gained little recognition: the Discourse of Sustainability - Capitalism - China's Economic Expansion. It is sustained here that those three sides are connected and together they build a narrative that is self-perpetuating - at least up to a point. The Lacanian theory of discourse is applied to unveil a less obvious side of that relationship : the discourse of sustainability, as it is presented today is but a discourse of self-indulgence, since most of its versions discuss the possibility of "sustainable consumption", neutralizing the much more powerful discourse of "reducing consumption". China's economic success derives, in that sense from its ability to find a niche as the provider of consumption possibilities for Westerners.
\end{abstract}

Keywords: Sustainability, Lacan, Žižek, China.

\section{Resumo}

O objetivo deste trabalho é apresentar uma interpretação lacaniana de um fenômeno ainda pouco reconhecido: o triângulo socioeconômico entre o discurso da sustentabilidade, capitalismo e a expansão econômica da China. Sustenta-se aqui que esses três lados conectam-se e juntos constroem uma narrativa que perpetua a si mesma. A teoria lacaniana do discurso, bem como a obra de Žižek, são aplicadas para revelar um lado menos óbvio dessa relação, qual seja, o fato de que o discurso da sustentabilidade, como apresentado hoje, torna-se um discurso apologético dos excessos do consumismo ao substituir o discurso da "redução do consumo" pelo paliativo discurso do "consumo sustentável". A expansão econômica da China deriva em grande parte de sua habilidade em encontrar um nicho como fornecedora de possibilidades de consumo para os ocidentais.

Palavras-chave: Sustentabilidade, Lacan, Žižek, China.

\section{Introduction}

"Everybody wants to go back to nature, they just don't want to go on foot" attributed to Petra Kelly

"Everyone, sooner or later, sits down to a banquet of consequences."

\section{Robert Louis Stevenson}

In his acclaimed movie A Fost sau n-a Fost? (2006), director Corneliu Porumboiu tells us the tale of three main characters participating in a low-budget television talk shown somewhere in Romania's hinterland in 2005 . The show, conducted by a TV reporter that barely can make his ends meet, celebrates sixteen years of Ceauşescu's

\footnotetext{
Paper received in April 2010 and accepted to publication in June 2010.

${ }^{1}$ Professor at FGV-EAESP, Department of General Management. PhD in Business Management (FGV-EAESP, 2005). Address: FGV-EAESP, Itapeva, 474 - $11^{\circ}$ floor - Phone: +55 (21)3799-7740/7972 Fax: +55(21) 3283-2938 / Code: 01332-000 - São Paulo, E-mail: Antonio.gelis@fgv.br . 
deposition. It aims to answer a simple question: Had that town - Vaslui - watched a real revolution as many other parts of the country had, back in that anno mirabilis of 1989? Did Vaslui have any part in the 1989 revolution or its population had just gone to the streets after facts were consummated somewhere else and Ceauşescu had already been deposed? To answer that question, the reporter invites - not exactly with politeness - two citizens of the town: a retired widowed civil servant and an alcoholic high school teacher. The former drives his answers to personal matters, specially his memories of love about his deceased wife. The latter wants desperately to pose as a revolutionary hero, affirming that he already was at the town's main square minutes before Ceauşescu's deposition. He adds to his version recollections of an heroic confrontation with the police. But, since many of the viewers who participate in the show thorough an open phone line present evidence that the professor was lying, the show degenerates into a bitter session of brutal and humiliating questioning to the professor by the reporter, who insists in asking him variations of the question "Fost sau $n-a$ fost?", literally, "Was There or Wasn't There?". The question, being repeated on air to the point of humiliating the interviewee, denies itself: how could a revolution had took place if brutalization of Romanians by Romanians was still so widespread and commonplace?

This cinematographic metaphor suggests a good question to open this paper. How can sustainability be anything but an emptied word and concept when it revolves more and more about justifying the excesses of self-destructive capitalism? Wouldn't the modifications on the original meaning of that world have denied itself, like the idea of revolution in the movie? In other words, sustainability, born from the need to refrain consumption to sustainable levels by reducing its sociological determinants, has morphed, somehow, into an apologetic discourse through a contradictory concept: sustainable consumption. Organizations took the lead in abusing this new concept and, by doing so, had fallen into a trap that threatens to bite back, much sooner than latter.

For many years already, both the academic and executive literature have been producing an always increasing number of theories, articles, books, movies and ideas about correcting the excesses of corporations and governments, aimed at developing a 'new and improved' corporation (v.g, BONIN; GÖRNER, 2010; BROOKFIELD, 1991; ESTY; WINSTON, 2009; MAKOWER; PIKE, 2008; SHRIVASTANA,1995). At first that trend would gather around the idea of sustainable development. But the trend's unassumed ultimate and more recent buzzword could be defined as being sustainable consumption, the idea that we can have it both ways: preserving natural resources and at the same time consuming more and more nice trips, nice food, cars, retirement pensions, houses, houseware, pharmaceuticals, electronic appliances, anti-terrorism high-level security, books, e-books, 3d-movies, academic meetings at romantic places in South America, energy and more energy, - renewable or otherwise - education, notebooks, newer notebooks, even newer notebooks, yoga classes, millions and millions of acres of limitedly available agricultural land to plant more and more sugarcane and corn to produce more and more 'renewable energy', elections in Iraq and in Afghanistan, the wars needed to guarantee them and so on. On the other hand, an almost exactly cotemporal development took place, that is, the astonishing economic and geopolitical expansion of China.

I argue here that those developments are not unrelated. Back in the late 60's and specifically after the oil crisis of 70's, facing the unsustainable consumption of natural resources needed to keep consumism going on, since it already was a much needed source of societal control, Western-minded societies and elites throughout the world developed a self-apologetic discourse in order to avoid facing the threat of reduced consumption: they developed the discourse of sustainable consumption. China's role on this model was one of being (at least initially) the 'carpet' under which western societies would swept their need for more and cheaper products and the unavoidable by-products of such production, which could not be accepted by the 'benevolent newspeak' of sustainability of consumption: over-exploitation of resources (including human resources), pollution and erosion of human rights as defined in the Western world. That model worked efficiently for many years, but it has now reached a crossroad, for the creation of something which I call here the 'Chinese model', threatens to overcome the creator. Western-minded organizations now face hard decisions, which boil down to a single one: how to compete against the higher competitiveness of the Chinese-model. Even if China itself fails (something that would be, by itself, a global economic catastrophe), the ongoing Western model would rapidly create "another China" to keep itself indulging in its addiction to pathological consumption. 
In the EPA journal, the trend towards trying to have it both ways was made clear already by Russell Train in 1992, when he affirms that

"Economic and environmental well-being are mutually reinforcing goals that must be pursued simultaneously if either one is to be reached. Economic growth will create its own ruin if it continues to undermine the healthy functioning of Earth's natural systems or to exhaust natural resources. By the same token, healthy economies are most likely to provide the necessary wherewithal for investments in environmental protection. For this reason, one of the principal objectives of environmental policy must be to ensure a decent standard of living for all (TRAIN,1992)";

This middle-of-the-road position would eventually become the mainstream approach to sustainability. Instead of a really efficient alternative to mainstream business, it would add a new layer of consumption to those already existent. Green Business became Big Business, after all. Maybe sooner than later we'll even hear of "Big Green" pretty much as we can hear about "Big Pharma".

In order to understand why and how we've failed to notice and to combat that process, I refer here to Lacan and one of the most important Lacanian thinkers of our times: the Slovenian philosopher Slavoj Žižek. My point is that a lot of this process is understandable with the help of a concept that Melman (2003) has called l'homme sans gravité, the weightless and excess-obsessed human being that can not help to be caught in the net of a nouvelle économie psychique, the new psychological economy, one that demands to the citizen to reduce his or her identity to the condition of consumer, immersed in the cruel excess of jouissancef ${ }^{2}$. In that net, China takes more and more the symbolic position of 'Big Other', the Master organizer of our behavior.

This paper is structured as follows: after this introduction, a review of relevant economic and social facts is provided, then I present in more detail the "Official Critical Narrative", showing how it is endogenous and dependent to the very model it criticizes; in the section about the "Other Critical Narrative", I show how China's expansion can be related to the developments that also led to the creation of the "official critical narrative". Then, in the section "Connecting both Narratives: A Žižekian-Lacanian (B)ridge", It is presented a brief review of Lacan and Lacanians in the organizational field, as well as a framework for understanding our "symbolic plasticity", needed to accept the flaws in the model. In "Hard Choices Ahead", I discuss implications of the previous reflections, trying to anticipate how current development could impact organizations.

\section{A brief review of relevant facts}

"Consuming less may be the single biggest thing you can do to save carbon emissions, and yet no one dares to mention it. Because if we did, it would threaten economic growth, the very thing that is causing the problem in the first place".

Tim Jackson, New Scientist, 15 Oct 2008.

In 1983, the General Assembly of United Nations approved its Resolution 38/161, named "Process of preparation of the Environmental Perspective to the Year 2000 and Beyond" (UNITED NATIONS, 1983). In that resolution the institution decided to create a Comission with the goal of, inter alia, "to propose long-term environmental strategies for achieving sustainable development to the year 2000 and beyond" (UNITED NATIONS,1983, article 8a). In 1987, the Commission's report was issued (UNITED NATIONS,1987). Sustainable development is defined there:

\footnotetext{
${ }^{2}$ A Lacanian concept, usually left untranslated in English (EVANS, 1996, p.91-92; FINK, 1995, p.xii). The paradox pleasure the subject derives from the satisfaction of his symptom. Evans, 1996, p.92).

${ }^{3}$ (B)ridge: Lacan's work is based on the central idea that the human unconscious was structured as a language. He has written in a sometimes obscure language and has made use of a huge amount of puns and neologisms. I define (B)ridge here as something that could eventually be grounds for communicating and bringing together, but that also demands some work of parts involved in order to do so. If not, it is more of a ridge, keeping apart and creating difference.
} 
"In essence, sustainable development is a process of change in which the exploitation of resources, the direction of investments, the orientation of technological development and institutional change are all in harmony and enhance both current and future potential to meet human needs and aspirations (UNITED NATIONS, 1987, Chapter 2, I/15)";

A trend has started here. From them on, whenever people started to talk about sustainable development, that would always be made with two main implicit conditions: (a) it should be done in the vaguest of terms and (b) it should never talk about reducing consumption. At first, this text may seem to have established a framework for defending sustainability. A closer look, however, shows that it also has created a implicit punishment, since anyone positioning him or herself in a different way would be an extremist or a fringe activist. By establishing an ideological center, it has automatically created an ideological periphery. That definition says as much through what it contains as through all it keeps out. No limitations are established to human material desires. That option, however, could only be achieved through major - one would say revolutionary - technology, specially concerning new sources of energy and natural resources. As we know, such breakthrough hasn't been reached yet and no one can be sure if it will ever be. In order not to leave any doubts about its position, the report clarifies:

"As for non-renewable resources, like fossil fuels and minerals, their use reduces the stock available for future generations. But this does not mean that such resources should not be used (UNITED NATIONS, 1987, Chapter 2, I/12)";

In fact, already in 1972 the United Nations had published a document concerning protection of the environment. In its Declaration of the United Nations Conference on the Human Environment (UNITED NATIONS,1972), it stated that

"Man has constantly to sum up experience and go on discovering, inventing, creating and advancing. In our time, man's capability to transform his surroundings, if used wisely, can bring to all peoples the benefits of development and the opportunity to enhance the quality of life. Wrongly or heedlessly applied, the same power can do incalculable harm to human beings and the human environment. We see around us growing evidence of man-made harm in many regions of the earth: dangerous levels of pollution in water, air, earth and living beings; major and undesirable disturbances to the ecological balance of the biosphere; destruction and depletion of irreplaceable resources; and gross deficiencies, harmful to the physical, mental and social health of man, in the man-made environment, particularly in the living and working environment (UNITED NATIONS, 1972, preamble, 3)”;

So at that moment in time an option was made: no talk about sustainability should suggest reduction in the levels of consumption in absolute terms. That option could look nowadays as being the only possible back then; however, it only takes to look at another organization, that also in 1972 has published a very different assessment of human-environment relationship - the Club of Rome - in order to notice how different could that decision have been. Founded in 1968 and composed by members of academy and business, the Club of Rome would be famous for its publications, the most well-known of which is a book they commissioned in 1972: Limits to Growth (MEADOWS; MEADOWS; RANDERS,1972). Authored by a group of MIT researchers, the book announced that the ongoing capitalistic economic model wouldn't be able to sustain itself due to a forthcoming and inevitable lack of resources. Widely prayed for its innovative approach but also widely criticized for some people for its affirmation about depletion of natural resources, in 2008 the authors' thesis was vindicated by a research organized in the Australian national body for scientific research, the Commonwealth Scientific and Industrial Research Organisation, more widely known as CSIRO. In his Working Paper A Comparison of The Limits to Growth with Thirty Years of Reality, Turner (2008), affirms:

"This paper focuses on a comparison of recently collated historical data for 1970-2000 with scenario presented in The Limits to Growth. The analysis shows that 30 years of historical data compares favorably with key features of a business-as-usual scenario called 'the standard run' scenario, which results in collapse of the global system midway through the $21^{\text {st }}$ Century. (TURNER,2008, Abstract). [...] this scenario results in global collapse before the middle of this century (TURNER, 2008, p.37)"; 
So, it can be said that 35 years ago our society had the opportunity to position itself on a track that could have led to a more balanced human existence. However, it has opted by a very different way, through which depletion of world resources accelerated as predicted in the book Limits to Growth. Game-changing technology that could make all that discussion pointless failed to materialize so far.

\section{China: A brief history of its meaning from a western perspective}

"Mr. Deng's men gallantly say that their economic reforms will continue, but they are almost certainly whistling in the dark."

The Economist, 24/01/1987

Approximately at the same time that the above described process took part, an "old new factor" arrives at the scene: China. A good summary of its impact can be found in Martin Jacques' book 'When China Rules the World':

"The mainstream Western attitude has held that, in its fundamentals, the world will be relatively little changed by China's rise. This is based on three key assumptions: that China's challenge will be primarily economic in nature; that China will in due course become a typical Western nation; and that the international system will remain broadly as it is now is, with China acquiescing in the status quo and becoming a compliant member of the international community. Each of these assumption is misconceived (JACQUES, 2009, p.12)";

That this is a misconception is something that we can find evidence of in Figures 1 and 2 below.

In Figure 1 we can see how spectacular China's economic expansion has been. Back in 1980, just thirty years ago, China's economy was smaller than Brazil's. At that point of time, China's GNI measured through the purchasing-power parity method was approximately $60 \%$ of Brazil's and 9\% of United States' GNI. By 2008, however, figures have changed immensely. On that year, China's GNI was 4,1 times as big as Brazil's and about 56\% of United States's GNI. For 2014, the International Monetary Fund (2010) predicts an even more impressive scenario: by then, accordingly to the international organization, China's GDP (PPP method) will be almost 6 times as big as Brazil's and will correspond to 86\% of United States' GDP.

Figure 1: Economic growth: Brazil, China and US, $1980-2008$

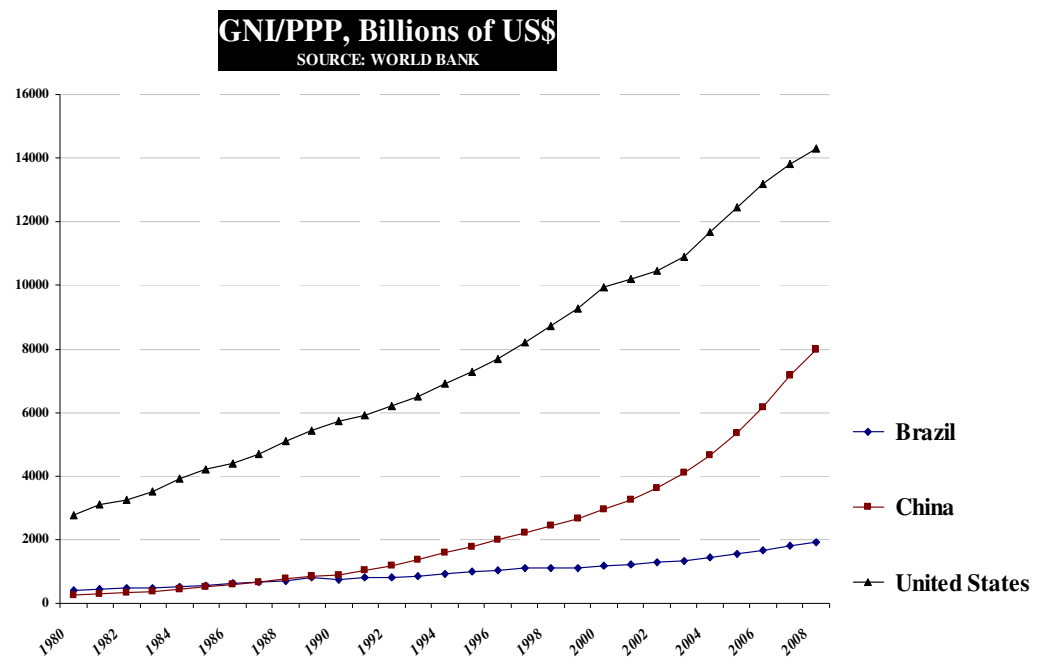

SOURCE: World Bank (2010).

What happened since 1980 in order to make China so powerful? Figure 2 gives us some hint. United Nations defined in 1998 the concept of Merchandise Trading: 
"Goods which add or subtract from the stock of material resources of a country by entering (imports) or leaving (exports) its economic territory. Goods simply being transported through a country (goods in transit) or temporarily admitted or withdrawn (except for goods for inward or outward processing) do not add to or subtract from the stock of material resources of a country and are not included in the international merchandise trade statistics. In many cases, a country's economic territory largely coincides with its customs territory, which is the territory in which the customs law of a country applies in full (UNITED NATIONS, 1998, p.14)";

Figure 2: China's merchandise trade: 1960-2010.

\section{China: Merchandise Trade (\% GDP)} SOURCE: WORLD BANK

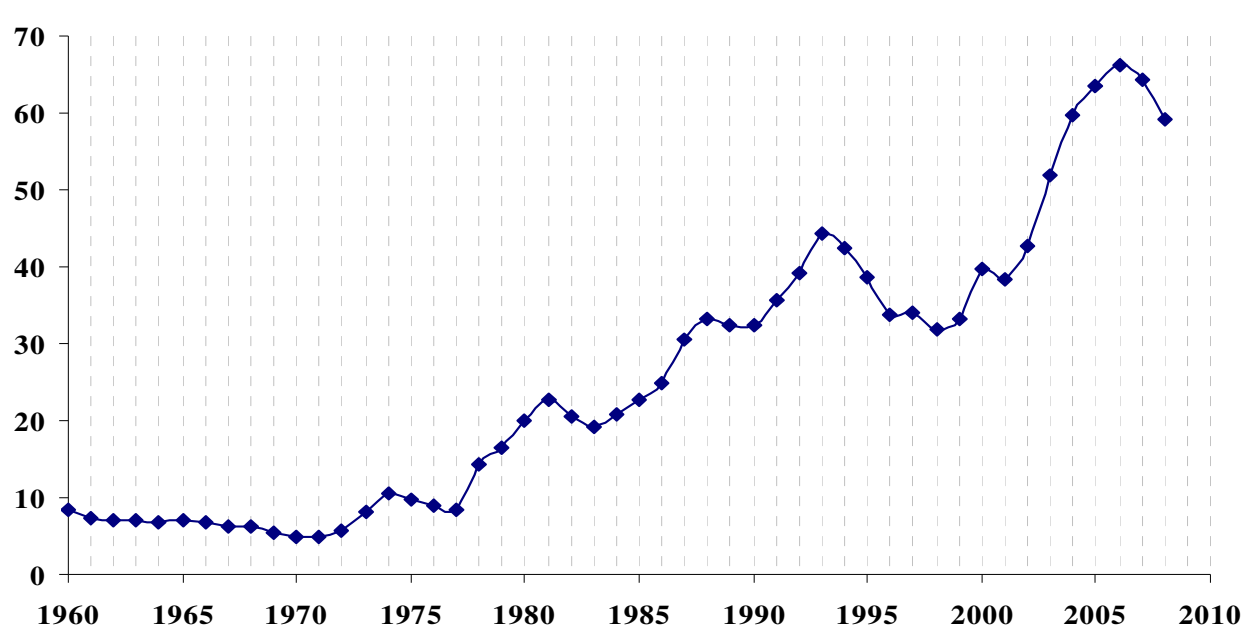

SOURCE: World Bank (2010).

In other words, Figure 2 captures the unusual growth of China's international trade as a percentage of her economy. So, the tale that Figures 1 and 2 tell us is that China's economic growth has been largely moneyed from the outside.

Looking at Figure 3 below, we can see that not only China's growth has been huge and fuelled by foreign trade; it was also mainly pushed by industrial production. In an age when we can hear everywhere that we live in an economy of services, the big intruder inside the developed world's party is a country that have decided to grow old-fashioned style: by adding value to raw materials through industrial activity.

Jacques (2009, p.12), reminds us that "the effects of China's economic rise are being felt around the world, most notably in the falling price of many consumer products and the rise, until the credit crunch, in commodity prices". China has sold to the West the only resource the country could offer: an huge reserve of cheap labor, ready to be used for production at very low prices. China's demographics was put to use by the country's leadership. Even if China's strategy presented a series of challenges to West's labor and even human rights structure, the temptation of such cheap products was too strong to be resisted. West was addicted to Consumism and cheap products were irresistible. Add to that the lure of huge profits and the plot was ready to unfold. For the first time since at least WWII, a country finally managed to get not only so economically strong to the point of being heard in the international organizations around the world but it had also done that keeping its geopolitical autonomy. 


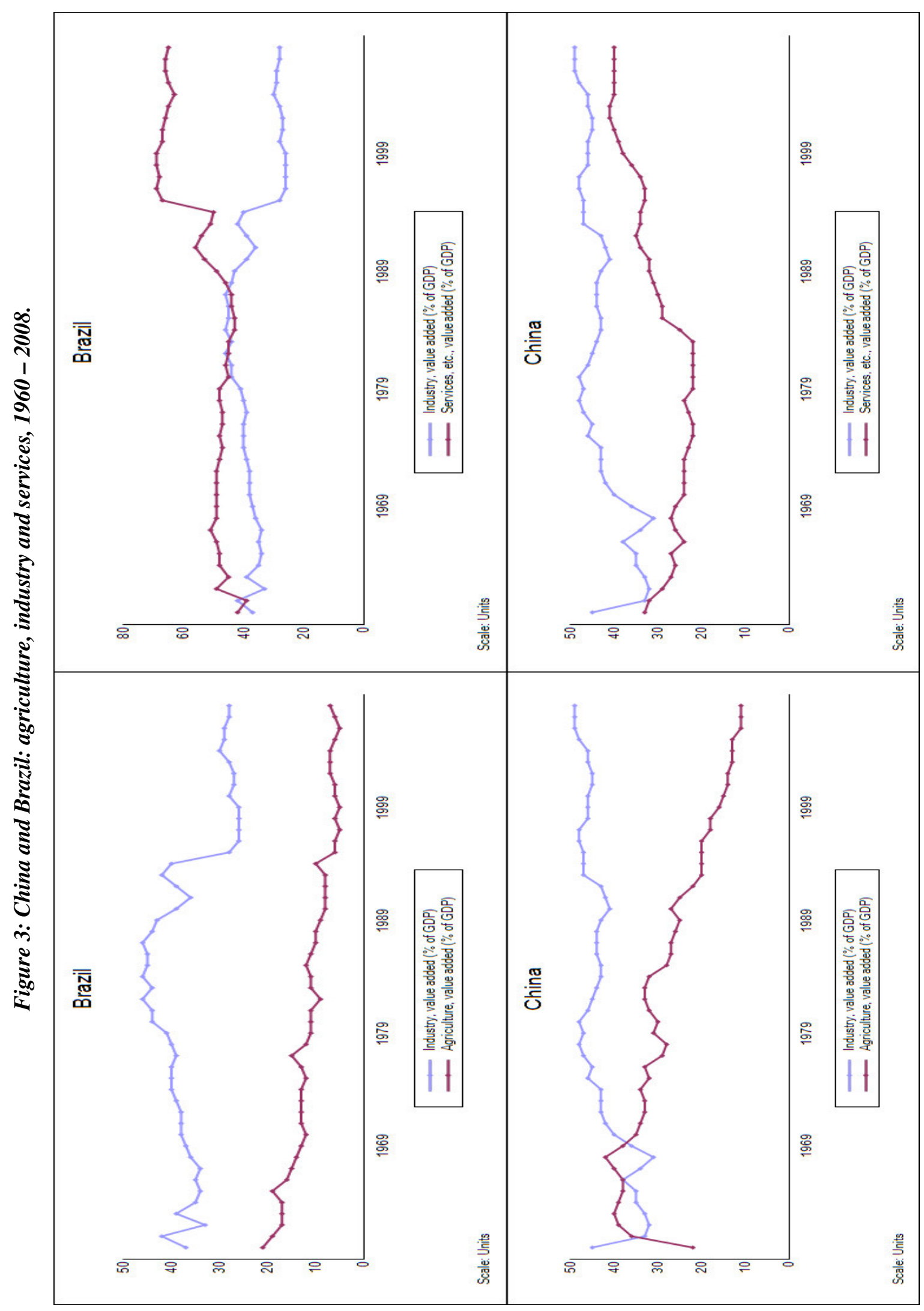

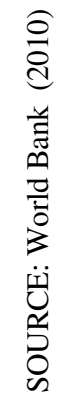


In a certain way, a curious historical metaphor can be developed here. The $19^{\text {th }}$ century had watched Cina's decadence as a world power. Around 1830, Commissioner Lin Zexu, trying to reduce the illegal export of opium from India to China, mainly by British merchants, sent a letter to Queen Victoria, asking her why did her government outlaw opium at home but encouraged its export to China. Not much time later, the Royal Navy seized Hong Kong and fought the so-called Opium War to conquer the right to free ports in China (FENBY, 2008, p.9). Now it is the West that just cannot avoid to resort to China in order to get the products it is addicted to. In a sense, a new opium war has been launched. This time, however, China has not so far been posed as the loser.

\section{The "official critical narrative"}

The above presented information and data allows us to built a model of how China and the West are related to each other. It is called here the "official critical narrative", since it denounces, as usually presented by mainstream media and sectors of academic world, the flux of power in that relationship, represented on Figure 4.

Western economies and, up to a point, Westernized sectors of non-developed economies exchange money for cheap goods in China. That allows the organizations in the West world to profit, even if it (1) promotes or at least ignores the extremely low labor conditions in China and environmental conditions set a much lower levels of acceptance than in the West; (2) promotes economic growth of a major autonomous geopolitical actor and (3) increases Western dependency on Chinese. On the other hand, such model sees - or at least it used to see until the financial crisis since 2008 - a interdependency between the two poles of that relationship, since China would be as dependent from the Western money as the West is dependent of Chinese goods.

\section{Figure 4: China-West relationship: the "surface".}

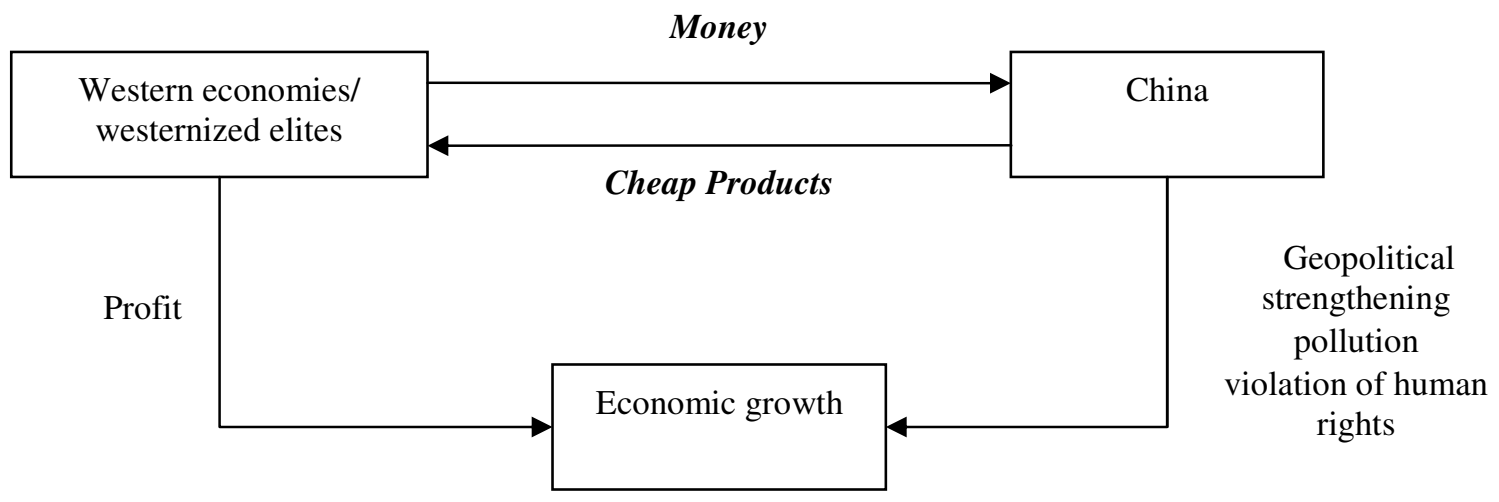

Source: Developed by the author

That position is quite adaptable to the idea of sustainable consumption. China is usually represented in that context as a example of how "not doing things", for its actions and its model of development. Moreover, at least until recently, that model allowed what Gelis Filho and Andrade have named "the Western illusions and the illuminist hopes in China" (2010), the idea that at some China will collapse, repent from its sins of geopolitical autonomy and embrace Western values. One example of those illusions can be read in Segal:

"DOES CHINA matter? NO, it is not a silly question-merely one that is not asked often enough. Odd as it may seem, the country that is home to a fifth of humankind is overrated as a market, a power, and a source of ideas. At best, China is a second-rank middle power that has Mastered the art of diplomatic theater: it has us willingly

suspending our disbelief in its strength. In fact, China is better understood as a theoretical power-a country that has promised to deliver for much of the last 150 years but has consistently disappointed. 
After 50 years of Mao's revolution and 20 years of reform, it is time to leave the theater and see China for what it is. Only when we finally understand how little China matters will we be able to craft a sensible policy toward it (SEGAL, 1999)";

Another example comes from Gilboy and Heginbotham:

"Many of today's senior Chinese officials recognize this dilemma but have powerful personal motivations to resist change. The next generation of Chinese leaders, however-set to take office in 2002-3 - is both more supportive of reform and less constrained by Tiananmen-era political baggage. These new leaders will likely respond to the dilemma, therefore, by accelerating political liberalization (GILBOY; HEGINBOTHAM, 2001)";

The problem with that model is that it ignores the central point of unbalance between the two poles. It creates the "guilt-free" consumer, that can buy gadgets and touristic trips at accessible prices, while criticizes the capitalistic model. That gap can be filled by looking at the non-expressed side of that relationship.

\section{The "other" critical narrative}

The movie The Beach (2000) shows the travails of an young American tourist in Thailand. After some initial happenings, he receives as a sort of inheritance from a fellow tourist a map that would supposedly take him to a paradisiacal beach, isolated from the mainstream track of predictable touristic pursuits. He finds that beach and, for a while, he sees himself in what could be described as some sort of suburban teen paradise: no parents, no usual societal conventions, a lot of liquor and cannabis, even some sex. All the "chosen few" tenths of foreigners live there in a kind of hippie community with higher standards of personal hygiene. There is a lot of comradery and fraternal love. No major problems, until something happen. One of the tourists is severely hurt by a shark while fishing. The bite gets infected and reality arrives to paradise, in the form of a constantly screaming-out-of-pain Nordic youngster. After some initial hesitation, the burden of facts is too heavy a load and the need to denial wins: the victim is taken far away from their eyes - and ears. As the main character reveals to the viewer in his retrospective narrative thoughts, "it would be harder to act if it wasn't so damn effective". The victim eventually dies and the problem seems to have vanished - but paradise was already lost. From then on, trust is forever gone among them and the illusion of sustainability of their collective dream is the one to vanish away.

That is a good metaphor of what I call here "the other critical narrative", represented graphically in Figure 5. It works as an undertow that prevents the changes that the "official discourse" seems to crave. It works by excluding essential facts and so acts by way of a non-speech that is aimed at isolating from debate the very questions that could in fact transform reality.

Figure 5: China-West relationship: the "undertow".

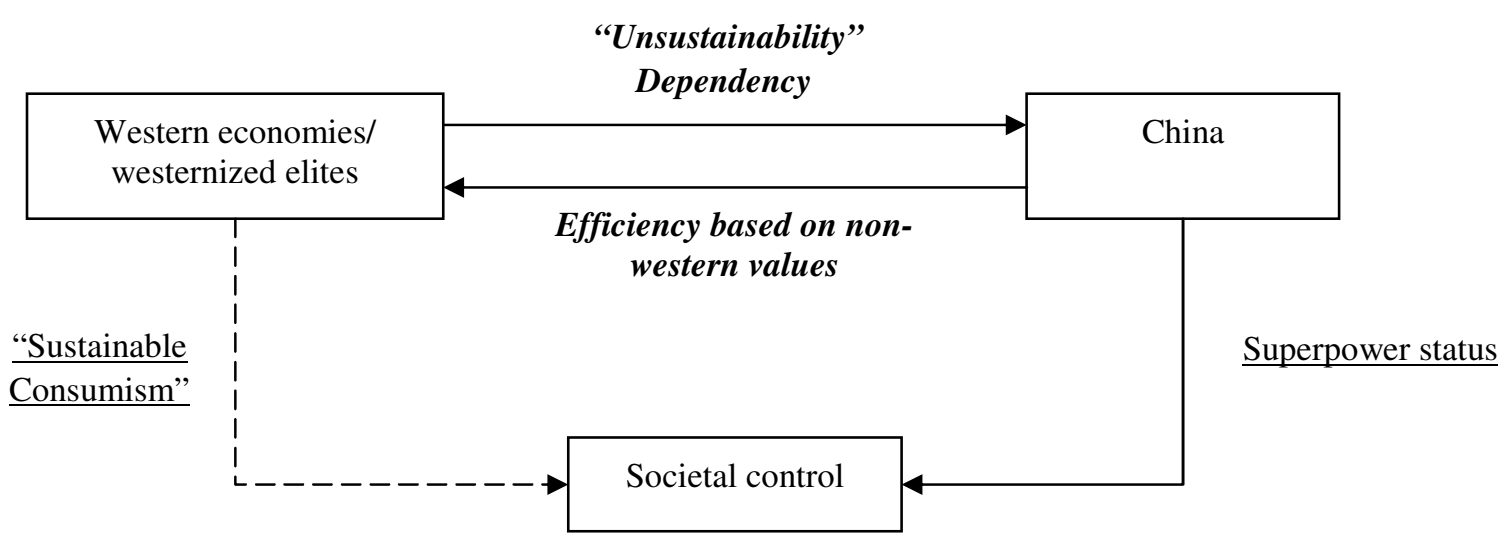

SOURCE: Developed by the author. 
While the "guilt-free" consumption runs amok, the official discourse criticizes the very system that provides their consumers which cheap and affordable goods. The transformation of citizens in consumers accelerates. It becomes clearer that the symbolic and more important exchange between West and China is not the one of goods for money. West, in fact, exports to China the unacceptable aspects of its craving for consumption along with a growing dependency of that model. China, on the other hand, silently exports its "way of doing things" to the West. As time goes by, "West transfers" to China more and more power, since its core values are substituted by credit-driven consumption, something that couldn't be modified even after the collapse of Western finances in 2008. Government intervened in order to save the banks; this model gives us an explanation of why: consumption is the major anchor of identification; a non-consumer is a non-person. Societal control become unattainable without that dependency. That should not considered something new. Marcuse (1991) had already explained the high levels of societal control allowed by the post-industrial societal organization. He didn't count, however, on the need of transferring to a third-party the productive part of the process. In a sense, one could see here an impetus of capitalism that pushes it towards new economic frontiers, reinventing itself in a "new and improved" way. The next question to be faced is how and why we did accept such state of things.

The role of organizations here is one of presenting repeated declarations of faith in sustainable consumption while producing more and more services and goods. As more and more of production is transferred to China, more and more the typical Western organization can focus on becoming more humane and eco-friendly: someone else is doing the stuff. However, as the crisis in 2008 has shown us, such situation must be based on the growth of services, specially financial ones. Credit, based in real wealth or virtual, is an essential part of the puzzle, since it allows the consumer to keep buying things, a sine qua non of that system. Meanwhile, the Chinese government (and also others, specially India's) needs to deliver to its population economic and geopolitical growth. Sic Transit Gloria Mundi.

\section{Connecting both narratives: a Žižekian-Lacanian (b)ridge}

"Working in the service of the Master signifier, more or less any kind of argument will do, as long as it takes on the guise of reason and rationality.

Fink, 1995, p.133

If nobody wants the world to be polluted; if no one accepts the destruction of the environment; if millions of people vote for environmental-friendly politicians, why on Earth things do not get done? Moreover, no one is consciously thinking about falsifying the discourse of sustainability. But things do not get much better, much on the other hand.

One way of looking at it is to looking for evil ones. That has two advantages: (1) it transfers guilt to other people and (2) it makes us the good ones. It is comfortable being able to believe that someone else is guilt of destroying the environment, while I have substituted eco-friendly batteries for regular ones. The fact that those batteries are supposed to be put inside a new energy-gauging notebook is something that I keep out of my mind. It is better and easier to look for guilt ones.

The answer here can only be found in the obscure world of unconscious collective beliefs. Obscure indeed, but nonetheless essential if we want to understand why so often in history societies took decisions that are clearly against their best interests. Of course, one cannot talk about unconscious phenomena without thinking about psychoanalysis. And psychoanalysis has a long history inside the organizational world. For instance, Eugène Enriquez, in his "L'Organisation en Analyse" (1992) applies Freudian concepts to interventions inside organizations. Arnaud (2007), analyzing the works of Gérard Mendel, comments that "one of the principal merits of Mendel's socio-psychoanalysis lies in the fact that it strives to understand how organizational reality influences individual psychic reality, including in its unconscious dimension.”. 
Lacan, himself one of the most important psychoanalysts of all time, has shown up more frequently in the realm of organizations. Gunder (2003) affirms that "Lacan provides an explanation for the role rhetorical discourse plays in shaping belief both within planning practice and for public acceptance of planning policy".

In a nutshell, we can say that the main route through which "bad organizational or societal psychic deals" are built is through discourse. We usually understand discourse as some sort of public speech. That, however, is a very poor notion. Fairclough (1992, p.63) defined it as being "a form of social practice, rather than a purely individual activity or a reflex of situational variables". But the meaning of this word that really interest us here is the one present by Lacan: "discourse is a social bond, founded in language" (LACAN,1975,p.21). Discourse, in other words, is that something that people built among them while exchanging communication, conscious or unconsciously. That definition is the tip of a huge iceberg that is Lacanian theory of discourse. As Mark Bracher has put it:
"In short, because it best explains how discourse affects the collective aspects of subjects' subjective economies (and hence also their actions), Lacanian theory offers the possibility of understanding and intervening in the social effects of culture with considerably more efficacy than other theories have enabled us to do (BRACHER, 1993, p. 13)";

But, as Fink remind us (1995, p.129-130), psychoanalysis is not a discourse of power. As such, it does not intend to be The Discourse, but only one among many others. The reason why we should pay attention for it is just the fact that it allows us to understand the functioning of different discourses in a unique way. Chung (2007) has applied Lacanian Theory of Discourse to analyze power relations in the Korean Public Administration. Stavrakakis has summarized possible applications of Lacan in the organizational field of knowledge:

\begin{abstract}
“This paper argues that Lacan's teaching has the potential to enrich discussions within this field and to suggest fruitful orientations for future research. Analyzing some of the central concepts and theoretical logics introduced by Lacan (such as lack, desire, the symbolic, enjoyment and fantasy), it explores the desire behind identity construction (agency), the reliance of this desire on processes of subjection to the socio-symbolic order (structure), as well as the limits marking both these domains. It argues that Lacanian theory can illuminate the (negative) dialectic between subject and organized Other and account for obedience and attachment to organized frameworks of social life in two ways: first, by focusing on the symbolic presuppositions of authority and power; and, second, by exploring the role of fantasy and enjoyment in sustaining them and in neutralizing resistance (STAVRAKAKIS, 2008)";
\end{abstract}

And what is Lacan's Theory of Discourse about? It is interesting to define it by resorting to an impossibility. The impossibility in question here is that of real communication. By real communication I mean here the building of a bringing together that is inherent to discourse. It shouldn't be understood, however, as some sort of new age utopian harmony among human beings. Much on the other hand, it is transitivity existent in any interaction, be it judged right or wrong, be it valued as good or bad. Discourse is much beyond the mere concept of language, in the sense of a set of rules to utilize sensory messages to exchange information. Language, as such, is what computer are programmed with; everything else that is lacking, everything else that make such "languages" so non-human, that surplus is discourse. The only thing we can do with languages is to "talk" them; but we always act (also verbally, but not exclusively) discourses. More precisely, discourse acts through us. As explained by Marshall Alcorn:

"Lacan argues that a subject can take different "positions" in respect to its reception of discourse. In his theory of the four discourses Lacan shows how four distinct discourse systems - discourse of the University, discourse of the Master, discourse of Hysteric and discourse of the Analyst-are produced by differing subject positions that the subject takes in relation to discourse (ALCORN Jr., 1994, p.4243)"; 
Those four categories encompass any specific discourse. Their names should not induce the thought that they are specific of institutions or personalities which somehow bear those names. Lacan insist in the social character of those discourses (KAUFMANN,1996,p.36).Bracher summarizes Lacan's ideas about discourse:
"Discourse, Lacan emphasizes, is 'a necessary structure' that 'subsists in certain fundamental relations' and thus conditions every speech act and the rest of our behavior and actions as well. These 'fundamental relations' are of several different orders: intrasubjective or psychological relations, intersubjective or social relations and relations with the nonhuman world. Discourse, according to Lacan, plays formative and transformative roles in each of these orders (BRACHER, 1994, p.107)";

Let's analyze the four main kinds of discourse.

The master's discourse. Lacan sustains that this discourse constitutes a primary discourse, for historical reasons and also both phylogenetically and ontogenetically. It had already been recognized by Hegel (FINK, 1995, p.130-131), Plato, Aristotle and Marx (KAUFMANN, 1996, p.330) . The Master addresses the one supposed to obey with an expression of power. As long as he is obeyed, the Master doesn't care about the knowledge being applied to production. And how does the Master obtain that? By creating a Master-signifier, an "original meaning" that must be obeyed "just because". Bracher (1994, p.117-120) remembers that Lacan's would identify philosophy, for instance, as a discourse of the Master. "As philosophers of the ordinary language school have realized for some time, philosophical works are ultimately nothing other than attempts to promote a certain way of speaking", affirms him. Lacan, accordingly to Salecl (1994, p. 169), has shown that the Master' essence resides on the fact that he is an idiot, who with his mere presence and not with his cleverness enables the functioning of the social reality (a King, for example). In his movie Aguirre, der Zorn Gottes (1972), Werner Herzog has shown how pathetic the condition of Master can become, specially when he fails in extracting production of his subjects supposed to obey. However, such discourse is rarely met nowadays in its more pure form. It has developed a kind of symbiosis with the next discourse.

The university's discourse. Not to be taken as being any discourse developed inside an University. The fundamental expression of Lacan's idea about this discourse is perhaps contained in his famous quotation, "for centuries, knowledge has been pursued as a defense against truth" (LACAN, 1996). Here, "knowledge" replaces the nonsensical Master signifier in the dominant, commanding position (FINK, 1995, p.132). The main point here is that this our first role in discourse. As children, even before we can speak, our experience of the world is largely determined by the Master-signifiers that drive our caretaker's worldview. Bureaucracy and education are two fields for the development of this discourse par excellence (BRACHER, 1994, p.115). Also accordingly to Bracher (1994, p.117), “[...] the University, insofar as Master discourse of overt law and governance is suppressed, functions as an avatar of the Master discourse, promulgating Master signifiers hidden beneath systematic knowledge".

The hysteric's discourse: This discourse takes its name from the condition that most clearly expresses it. The discourse of the Hysteric provides a refuse to accept - to embody - the Master signifiers that constitute the subject positions that society, through language, makes available to individuals; it is the exact opposite of the University's discourse, for the Hysteric goes to the Master and demands that he shows his stuff, prove his mettle by producing something serious by way of knowledge (BRACHER,1994, p.122; FINK,1995, p.133). But Bracher adverts us that,
"Despite its refusal to follow the Master signifier, however, the Hysterical subject remains in solidarity with it. This solidarity manifests itself in the wish of anxiety for security and stability, the search of meaninglessness for a meaning or identity, and the urge of shame to coincide with the ideal. This is the meaning of Lacan's warning to revolutionary students that what they were really asking for - and would get - was a Master (BRACHER, 1994, p.122-123)”;

It is a perhaps sad fact of history that "street revolutions", usually, just manage to reinforce their Master's position or to bring up new Masters. A recent example of such failure - measured by its own standards - is the 
so-called "Orange Revolution" in Ukraine (OLEARCHYK,2010). After much triumphalism and many expressions of the Hysteric's Discourse, next election brought back exactly their former Master.

The analyst's discourse: This discourse is the inverse of the Master's discourse, the ultimate subversive practice that undermines all attempts at domination and Mastery; by pointing to the fact that the analysand is not the Master of his or her own discourse, instate him or her to perceive his or her split subject and the Other's Master-signifier that is acting through him. Accordingly to Lacan, it is the only discourse that offers an effective means of countering the psychological and social tyranny exercised through language. Even if in the end the result is another Master-signifier, in the words of Lacan one ' shifts gears' (BRACHER, 1994, p.122124, EVANS,1996, p.46; FINK, 1995, p.136).

\section{Lacan's theory of discourse and the discourse of sustainability}

As it was shown, Lacan's four discourses encompasses every specific material discourse. How can we then analyze the discourse of sustainability? Sustainability's discourse can represent examples of the four discourses, not perfectly sequential:

\section{Phase 1 - Sustainability as the discourse of the analyst}

In a first moment, sustainability as proposed by the Club of Rome represented the Analyst's Discourse: by pointing to the Business and Government world that their behavior was non-sustainable in the long-run, it has pointed to an internal contradiction. It could had led to a new Master-signifier, for instance the "zero-growth economy" model, but the "analysand" wasn't ready to change; in fact it decided to keep acting its symptom of depredation and exclusion-building. That was made, at first, by morphing the discourses through which sustainability would manifest itself. The two immediate candidates were the Hysteric's and the University's discourses.

\section{Phase II - Sustainability as the discourse of the hysteric and as the discourse of the university}

As it was demonstrated, the opposition to the Master in the discourse of the Hysteric is a fake one. The Hysteric is looking for a reinforcement of the Master or for a new Master. On the other hand, the discourse of the University works through the guidance of the Master's discourse. Both discourses have manifested themselves in the field of sustainability. A good example of the first is the transformation of the debate about Climate Change into a crusade. Even nicknames have been created to identify "the enemy": 'deniers' and 'heaters'. For instance, a journalist that frequently denounces 'deniers' has written:

"No one should be allowed to speak on the Today programme until the interviewer is equipped to challenge them. But let's drop all this talk of keeping people we disagree with off the air. Let them say their piece but don't let them or anyone else get away with talking gibberish (MONBIOT, 2009)";

All the pseudo-liberal credentials are posted: the respect for freedom of speech and the 'greeness', but the content is Hysterical in the sense that it intends to confront power in order to extract of it some sort of manifestation. Also it is implied that anyone confronting the 'heaters' position is 'talking gibberish'. It is also implied that the University is expected to produce knowledge to sustain their claims and, by doing so, sterilizing opposition. Both sides in the argument have committed their peccadilloes . The biggest, however, is the fact that they got into the discussion sustaining the Master's discourse: talk about anything, as far as you talk about nothing. To the Master, the only thing that cannot be questioned is its right to drive other people's behavior. As far as they keep the apologetic discourse going on, it is no real contestation. As such, the whole Climategate affair showed how far from "Truth" is the game being played on (HARVEY, 2010). In the end those involved are just fighting for how better to please the Master. There is no real contestation going on here.

\section{Phase III - Sustainability as the discourse of master: green goes big}

Finally, sustainability morphs into a form of Master's Discourse. It is used now to justify the capitalist game. A new market trading carbon-emission rights is launched; companies, from oil to tobacco launches their own green campaigns. Finally, the position of leader in green technology moves to a predictable destine: China 
(OSTER, 2009). After all, if "green" has become just another business, adding a layer to the already existent layers, why not moving to the place that is absorbing every possible business?

At this point one could have the idea of branding those discoveries against the corporations and governments. That would be, however, just another instance of the discourse of the Hysteric. More profitable, from a psychologically point of view, would be to understand why we did accept such transformations. For that, we need the help of Žižek's work

\section{The sublime object of sustainability: a Žižekian approach to "green goes big"}

Slavoj Žižek's work has its roots in both the Marxist and Lacanian traditions. Considered one of the most important contemporary thinkers, his original approach to many different questions made his fame. One of his peculiarities is a strong ability to apply obscure Lacanian concepts to popular culture (ŽIŽEK,1991a). Žižek has been present also in the field of organizational studies. DeCock and Böhm, explained that

"The first 'face' of organizational liberalism is expressed through post-bureaucratic discourses which very much define the mainstream of management thought today, highlighting the need for organizational openness which can only come through a liberation of management from the closed structures of the bureaucracy. The second face of organizational liberalism defends the bureaucratic ethos of liberal democratic institutions and points to the Popperian concept of the 'open society' that requires rational, procedural laws to reconcile conflicting values in societies and organizations, thus ensuring the existence of a plurality of ways of life. We point to the limitations of both 'faces' of organizational liberalism by discussing key aspects of Slavoj Žižek's work. Žižek displaces the liberal conception of institutionally sanctioned 'openness' by claiming this actually constitutes a closure and puts a challenge to us. How can we create real openness? How is a real difference possible? (DeCOCK and BÖHM, 2007, p. 815)”;

Jones and Spicer (2005) applied the Žižekian concept of Sublime Object to entrepreneurship. Fleming and Spicer also applied his concepts in a different context:

"Most studies tend to envisage belief as something internal to the thinking and feeling person. We argue, however, that belief does not only reside 'inside' the individual subject but also in an external economy of objects and rituals. What we call the 'objectivity of belief' highlights how various things such as commodities, artifacts, machines and even other people may believe in our place. We develop these ideas by drawing on a rich tradition of social theory that includes Marx and Žižek, and apply it to the study of objects, belief and power in contemporary organizations (FLEMING and SPICER, 2005, p.181)";

The complex work of Žižek cannot be resumed here. Instead we'll focus in two concepts: ideology and the vanishing mediator. In his book The Sublime Object of Ideology, Žižek presents a radical idea: 'what is really at stake in ideology is its form, the fact that we continue to walk as straight as we can in one direction, that we follow even the most dubious opinions once our mind has been made up regarding them'. (ŽIŽEK, 1989, p.84). As far as ideology is concerned, it only takes that one does not notice its only objective, self-fulfillment, for it to keep itself working.

But Žižek has identified two conflicting tendencies in late capitalism. On one hand, late capitalism directly commands the subject to enjoy, so enjoyment does not simply accompany one's duty. One's duty is to enjoy at all costs (DEAN, 2006, p.99). On the other hand, however, Žižek has also identified a decline of symbolic efficiency in late capitalism's institutions. As presented by Dean (2006), "the decline of symbolic efficiency refers to the ultimate uncertainty in which late capitalist subjects find themselves.

So, the "late capitalist subject" has an ideology - Consumism - but the symbolic efficiency to believe on it is lacking. That helps to explain the self-damaging morphing of sustainability's Discourse content: it is acting as a vanishing mediator, a concept originally proposed by Jameson (1988) and much developed by Žižek (1991b). 
It has been defined as being "a concept which somehow negotiates and settles - hence mediating - the transition between two opposed concepts and thereafter disappears.". Dean gives us a very interesting example

"The closed society of medieval capitalism does not automatically or immediately transition into bourgeois capitalism. How do we get there? How is it possible to get from medieval corporatism to capitalist individualism? Protestantism. Protestantism extends the religious attitude beyond specific observances and into an ascetics of the everyday. Once the Protestant work ethic is universalized as central to economic life, it drops away or vanishes; religious activity can be relegated to the bourgeois private sphere (2006, p.110)";

So, now we can develop our framework to understand how the sustainability as discourse of the Analyst gave way to sustainability as discourse of the Master. In a society where late capitalism orders people to enjoy but a new economic Master - so far, China - is in need, you don't just wake up one morning and rationally decide to change things. You first must neutralize the discourse of the Analyst, in order to create conditions for a vanishing mediator - the need for sustainable consumption open the way to a new structure of domination. That way is now open.

\section{Hard choices ahead: towards a predictive model}

I try here to develop a predictive model of things to come. In spite of trying to be predictive, in an epistemological sense, this is not about trying to anticipate future developments. Much on the other hand, this endeavor limits itself to create the intellectual conditions for scenario-building. Also obviously, it is selfassumedly wrong from the start. As Alfred Chandler has put it, "all models are wrong; some of them are useful". So, the following model tries to shed light on a very complex - but yet based on a few central points relationship between West and China. The model is based on three assumptions:

- Assumption 1: There are no enough resources to keep the current levels of consumption, let alone increasing ones.

Before the huge financial crisis since 2008 - and maybe in part because of that - commodities reached very high levels and, in some cases, an all-time high. Anecdotal and statistical evidences of exhaustion are mounting. Moreover, China and, in lesser degree, India, demand enormous amounts of natural resources in order to keep their current levels of growth.

- Assumption 2: China will either keep growing at her current levels or will reduce her rate of growth/stop growing.

Both ways, West would have trouble facing the outcomes. In the first case, a growing pressure of a resourcethirty China would keep pressing Western economies. In the second case, the Chinese engine would cease to push the world economy ahead.

- Assumption 3 - Western societies are currently dependent on growing levels of consumption in order to keep internal societal control.

Based on that assumptions, we can analyze the possible scenarios. The first scenario, presented in Figure 6, is called "business-as-usual". Nothing really changes in the distributions of exchanges. Gradually, the transfer of power determines an erosion of societal control by Western Governments, unable to substitute Consumism as major tool of control. China's status consequently rises to one of global superpower. Western organizations in this scenario are positioned in a save-our-souls situation, lost in a world that is indifferent to the long used discourses of fake changes. It is not improbable, however, that many of them would cling even harder to useless discourses of sustainable consumption. This scenario, however, is a transitional one; after some time, it would evolve either to scenario III or IV, presented ahead in the text. 
Figure 6: China-West relationship: scenario I - "business as usual”.

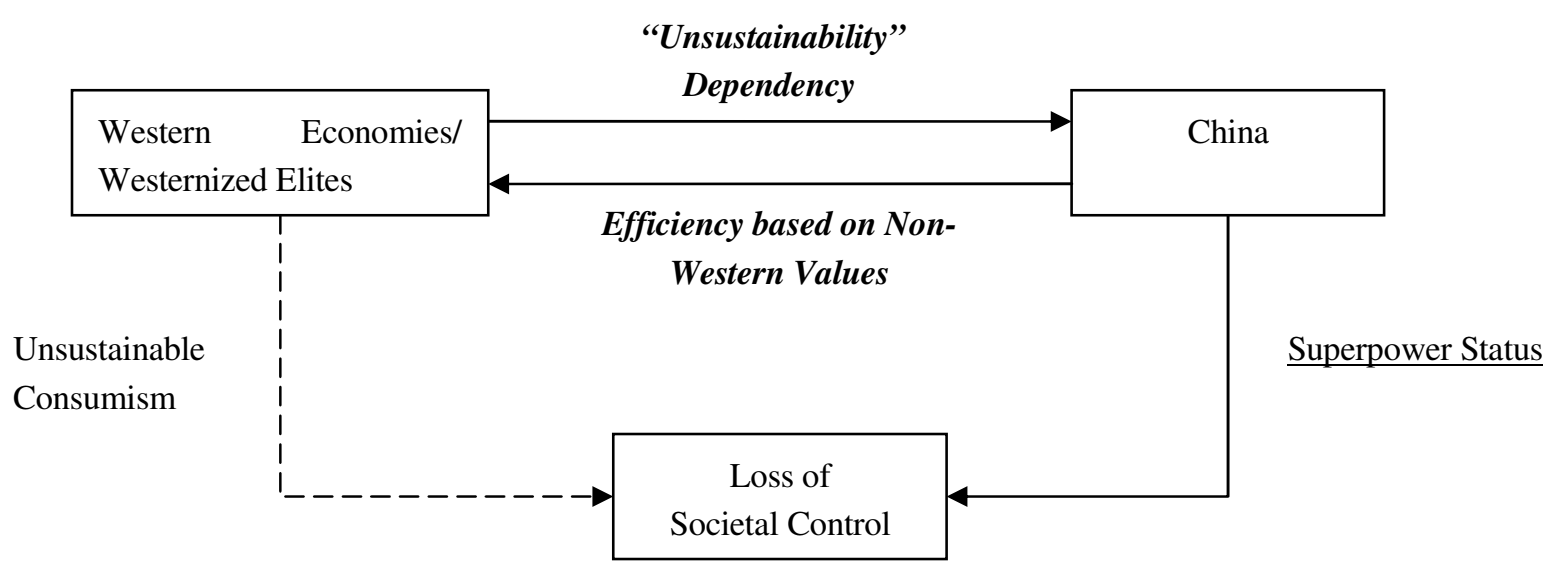

SOURCE: Developed by the author.

Scenario II, presented in Figure 7, analyzes the "China has Collapsed" situation. For many Analysts in the West, that would come as a bless. However, since the problem is inside Western societies, it would be more probable that a "new China" appeared, able to substitute the collapsed one.

Figure 7: China-West relationship: scenario II - "China collapses".

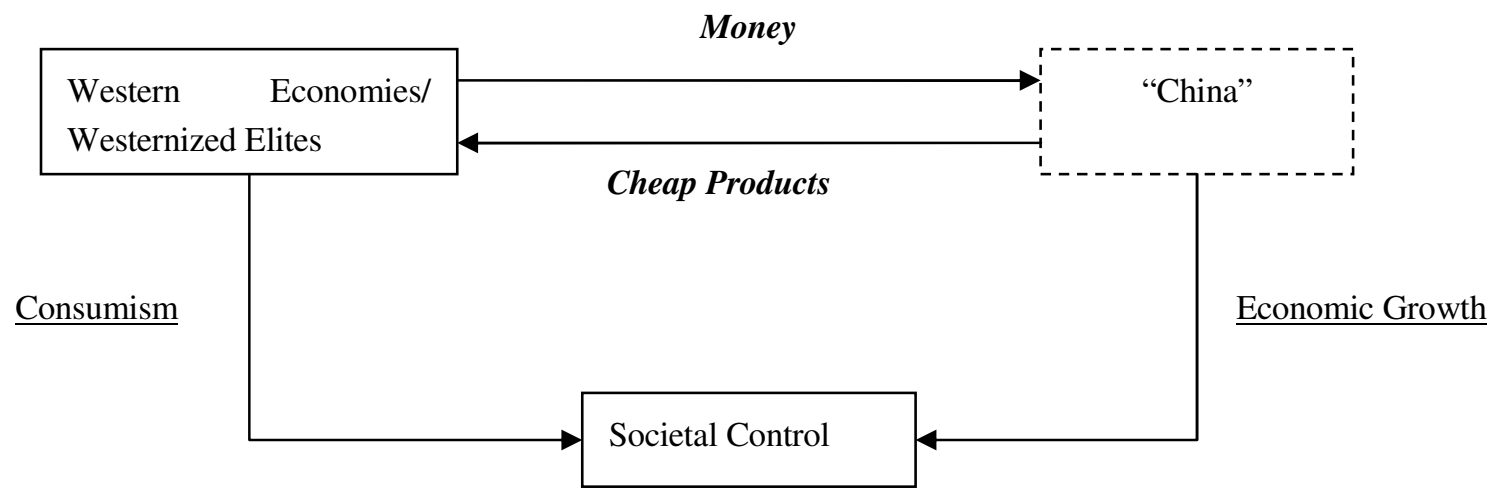

SOURCE: Developed by the author.

In Figure 8 we can see scenario III, called "China Wins". A possible development of scenario I, it represents effectively the "conquering" of Western economic world by the Chinese Model. Western organizations adopt Chinese practices and star to questioning the practices developed so far. It is predictable that in such situation the discourse of sustainable consumption would develop into another apologetic discourse, probably by proposing some sort of humanized Chinese style of management. 
Figure 8: China-West relationship: scenario III - Chinese model "wins".

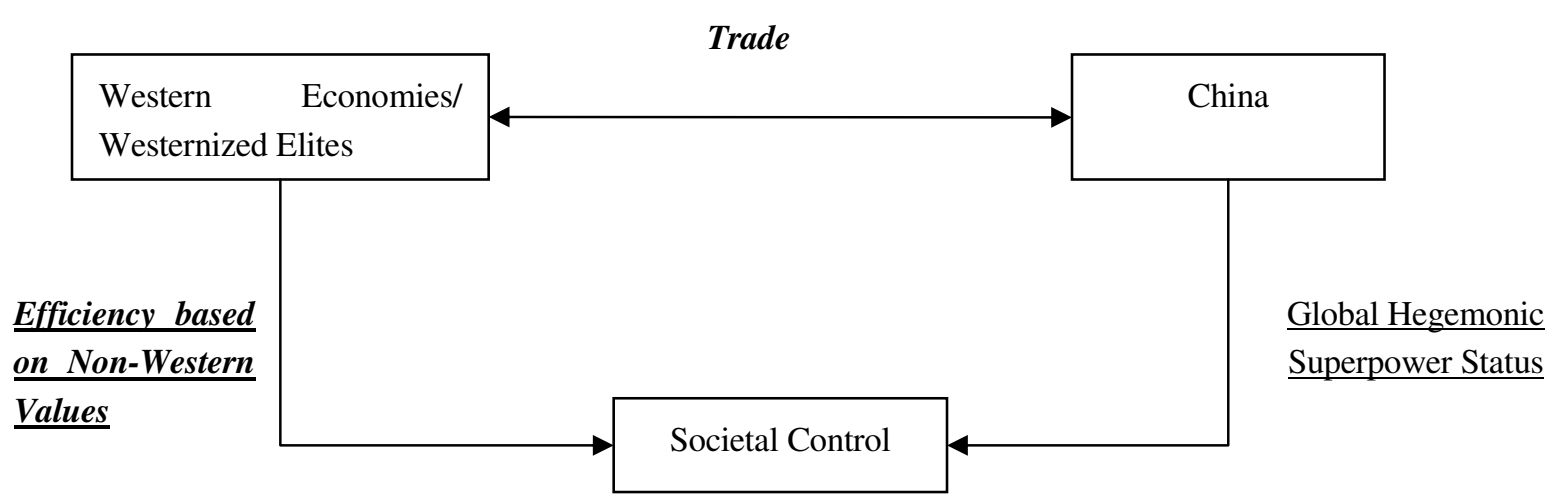

SOURCE: Developed by the author.

Figure 9 represents scenario IV, the only really transformational. It is based on the assumption that Western organizations and societies can either reduce drastically their levels of consumption, or that they can develop new and revolutionary technologies, specially in the energy field, and/or get access to new and unthinkably large reserves of natural resources. Since such sources of resources seem not to be left in our planet, it boils down to reduce consumption or to develop revolutionary technologies. The former, at least apparently, depends just on societal decisions. Moreover, this scenario also present a curious situation: free from its addiction - or at least able to afford it - West would break free from its current relationship to China, which would then face its own internal contradictions.

Figure 9: China-West relationship: scenario IV-alternative solutions.

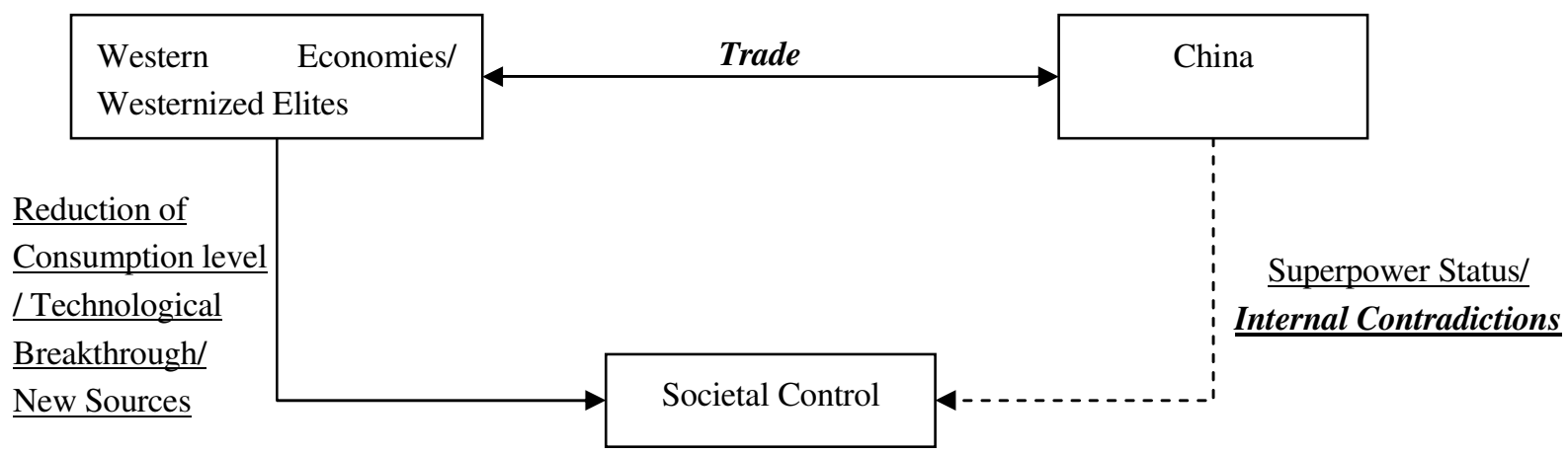

SOURCE: Developed by the author.

Finally, it is possible to organize the discussion of scenarios in a fluxogram, presented in Figure 10. The "China Collapses" situation is kept inside a different box in order to stress that it would not, by itself, changes West model of societal control in the long-run. 
Figure 10: China-West relationship: decision-making framework.

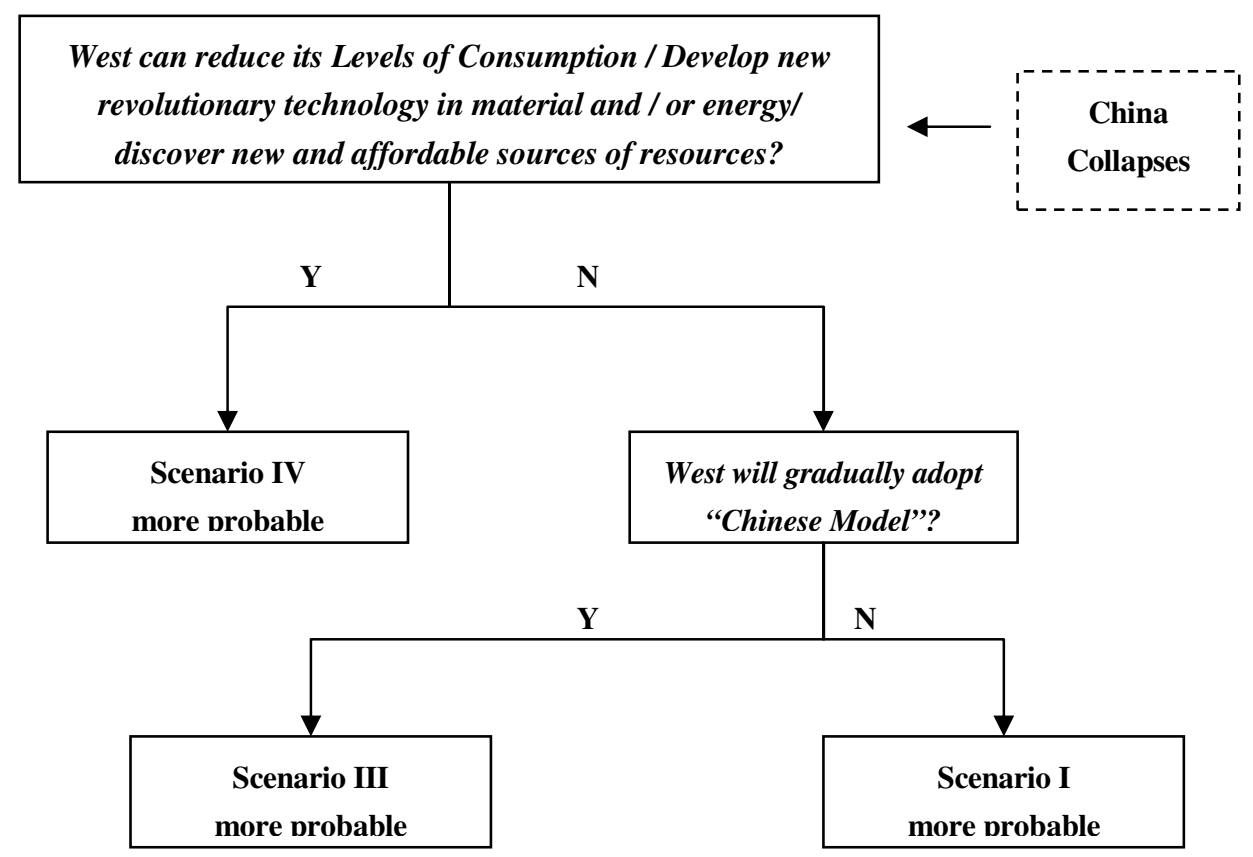

SOURCE: Developed by the author.

And where are we now? I'd say that, considering the decisions taken by Western governments during the crisis and the threat of sovereign collapse, we are at the first knot, slowly turning to the right, towards the adoption of the Chinese model. Unfortunately, facts unfolding in Western countries, do not seem to support the idea that we can do it without current levels of consumption. ${ }^{4}$

\section{Conclusion}

The China-West relationship characterizes a dynamic system. At first, such system would deliver the cheap goods needed by Westerners in order to keep their rate of economic and consumption growth. After a while, however, the resulting dependency and growth of China's international reserves inverted the polarity, causing Western societies to become more and more dependent on the apparently endless supply of Chinese opportunities for imports and investments. At this point, which is precisely the point where we are right now; some choices - hard choices - are presented to Western societies. If economists ever said something wise, it is probably the idea that "there is no free lunch". We are currently living in borrowed time. Either we change deeply - the way we live accordingly to our fundamental values and facing the need of unsustainability of current levels of consumption or we'll have to change it accordingly a different and yet unclear set of values. The only alternatives to that conundrum belong so far to the realm of wishful thinking. The role of organizations is a very complex one: on one hand they must profit; on the other, so far they have failed in decrease absolute levels of resources consumption. Moreover, the organizational world is still lacking a model of financial sustainability that could be based, in large scale, on delivering goods that are not supposed to be changed for newer ones on an increasing frequency.

\footnotetext{
${ }^{4}$ After this paper was finished a significant development took place. The Greek prime-minister, trying hard to explain how his country could possibly grow while also reducing its deficit, said that Greece would create thousands of green jobs. Empty speech in action, resorting to the discourse of sustainability.
} 


\section{References}

A FOST SAU N-A FOST? Director: Corneliu Porumboiu. Produced by Corneliu Porumboiu and Daniel Burlac. Romania: Bucharest, 2006.

AGUIRRE, DER ZORN GOTTES. Director: Werne Herzog. Production: Werner Herzog. West Germany, 1972.

ALCORN JR., Marshall W. The subject of discourse: reading Lacan through (and beyond) poststructuralist contexts. In: BRACHER, M.et al (Ed.) Lacanian theory of discourse: subject, structure and society. New York: New York University Press, p.19-45, 1994.

ARNAUD, Gilles. Poweract and organizational work: Gérard Mendel's socio-psychoanalysis. Organization Studies, v.28, n.3, p.409-428, 2007.

BONIN, Sheila; GÖRNER, Stephan. Making sustainability real. McKinsey Quarterly, issue 1, p.92-93, 2010.

BRACHER, Mark. Lacan, discourse and social change. [S.I.]: Cornell University Press, 1993.

. On the psychological and social functions of language: Lacan's theory of the four discourses. In: et al. (Ed.). Lacanian theory of discourse: subject, structure and society. New York: New York University Press, p.107-128, 1994.

BROOKFIELD, Harold. Environmental sustainability with development: what prospects for a research agenda? European Journal of Development Research, v.3, n.1, p.42-69, 1991.

CHUNG, Sung Ho. Reading Korean public administration: an application of Lacan four discourses. International Journal of Public Administration, v.30, n.12, p.1343-1369, 2007.

DEAN, Jodi. Žižek's politics. London: Routledge, 2006.

DE COCK, Christian; BÖHM, Steffen. Liberalist fantasies: Žižek and the impossibility of the open society. Organization, v.14, n.6, p.815-836, 2007.

ENRIQUEZ, Eugène. L'Organisation en analyse. Paris: Presses Universitaires de France, 1992.

ESTY, Daniel; WINSTON, Andrew. Green to gold: how smart companies use environmental strategy to innovate, create value, and build competitive advantage. New York: Wiley, 2009.

EVANS, Dylan. An introductory dictionary of Lacanian psychoanalysis. New York: Brunner-Routledge, 1996.

FAIRCLOUGH, Norman. Discourse and social change. Cambridge: Polity Press, 1992.

FENBY, Jonathan. The Penguin history of modern China: the fall and rise of a great power, 1850-2008. London: Penguin Books, 2008.

FLEMING, Peter; SPICER, André. How objects believe for us: applications in organizational analysis. Culture \& Organization, v.11, n.3, p.181-193, 2005.

FINK, Bruce. The Lacanian subject: between language and jouissance. Princeton, NJ: Princeton University Press, 1995.

GELIS FILHO, Antonio; ANDRADE, Daniel. Aspectos geopolíticos da crise: as ilusões ocidentais e as esperanças iluministas. Accepted for publication in 2010. Revista de Economia da PUC-SP, São Paulo. ISBN: 1984-8838, 2010.

GILBOY, George; HEGINBOTHAM, Eric. China's Coming Transformation. Foreign Affairs. v. 80, n.4, July/August, p. 26 39, 2001.

GUNDER, Michael. Planning policy formulation from a Lacanian perspective. International Planning Studies, v.8, n.4, p.279-294, 2003.

HARVEY, Fiona. Politicising and scare tactics cloud the issue. Financial Times, 9 Mar. 2010.

Available online at < http://www.ft.com/cms/s/0/2d0bfdbc-2b1a-11df-93d8-00144feabdc0.html>. Last access: 14 Mar 2010.

IMF - International Monetary Fund. IMF Data Mapper 2010. Available at: <http://www.imf.org/external/datamapper/index.php>. Last access: 12 Mar 2010.

JACQUES, Martin. When China rules the world: the rise of the middle kingdom and the end of the western world. [S.I.]: Penguin Books, 2009.

JAMESON, Fredric. The ideologies of theory. London: Routledge, 1988.

JONES, Campbell; SPICER, André. The sublime object of entrepreneurship. Organization, v.12, n.2, p.223-246, 2005.

KAUFFMANN, Pierre (Ed.). L'apport freudien: élements pour une encyclopédie de la psichoanalyse. Paris: Bordas. In: DICIONÁRIO enciclopédico de psicanálise. Translated by Ribeiro, Vera and Borges, Maria Luiza X. de A. Rio de Janeiro: Jorge Zahar, 1996. 
LACAN, Jacques. Le séminaire - livre XX: encore. Texte établi par Jacques-Alain Miller Paris: Seuil, 1975.

. Le séminaire - livre XX: l'object de la psychanalyse. Texte établi par Jacques-Alain Miller. Paris: Seuil, 1996.

MAKOWER, Joel; PIKE, Cara. Strategies for the green economy: opportunities and challenges in the new world of business. Columbus, OH: McGraw-Hill Professional, 2008.

MARCUSE, Herbert. One-Dimensional Man. 2nd ed. London: Routledge: 1991.

MARTIN, Jacques. When China rules the world: the rise of the middle kingdom and the end of the western world. [S.I.]: Penguin Books, 2009.

MEADOWS, Donella; MEADOWS, Dennis L.; RANDERS, Jørgen. The limits to growth. New York: Universe Books, 1972.

MELMAN, Charles. L’homme sans gravité: jouir a tout prix. Paris: Denöel, 2003.

MONBIOT, George. Should climate deniers be allowed to speak on the today programme? The Guardian, 13 Nov. 2009. Available at the

< http://www.guardian.co.uk/environment/blog/2009/nov/13/climate-deniers-today-programme >. Last access: 12 mar 2010.

OLEARCHYK, Roman. Yanukovich sworn in as Ukraine president. Financial Times, 25 Feb. 2010.. Available at the < http://www.ft.com/cms/s/0/20ace836-21fd-11df-98dd-00144feab49a.html >. Last access: 14 mar 2010.

OSTER, Shai. World's top polluter emerges as green-technology leader. The Wall Street Journal, 15 Dec. 2009. Available at

< http://online.wsj.com/article/SB126082776435591089.html>. Last access: 14 mar 2010.

SALECL, Renata. Deference to the great other: the discourse of education. In: BRACHER, Mark et al. (Ed.). Lacanian theory of discourse: subject, structure and society. New York: New York University Press, p.163-175, 1994.

SEGAL, Gerald. Does China matter? Foreign Affairs, p.24-36, Sep./Oct. 1999.

SHRIVASTANA, Paul. The role of corporations in achieving ecological sustainability. Academy of Management Review, v.20, n.4, p.936-960, 1995.

STAVRAKAKIS, Yannis. Peripheral vision: subjectivity and the organized other: between symbolic authority and fantasmatic enjoyment. Organization Studies, v.29, n.7, p.1037-1059, 2008.

THE BEACH. Director: Danny Boyle. United Kingdom;United States, 2000.

TRAIN, Russell E. A call for sustainability. EPA Journal, v.18, n.4, p.6-11, 1992.

TURNER, Graham. A comparison of the limits to growth with thirty years of reality. CSIRO Working Papers Series 20082009. Canberra: CSIRO Sustainable Ecosystems, 2008. Available at http://www.csiro.au/files/files/plje.pdf, 2008.

WORLD BANK. Data \& Research. $2010 . \quad$ Available <http://econ.worldbank.org/WBSITE/EXTERNAL/EXTDEC/0,,menuPK:476823 pagePK:64165236 piPK:64165141 theSite PK:469372,00.html>. Last access: 14 Feb. 2010.

UNITED NATIONS. Declaration of the United Nations Conference on the Human Environment. 1972. Available at: <http://www.unep.org/Documents.Multilingual/Default.asp?DocumentID=97\&ArticlelD=1503>. Last access: 17 Feb 2010.

. General Assembly. A/RES/38/161: process of preparation of the Environmental Perspective to the Year 2000 and Beyond, 19 Dec. 1983. Available at: <http://www.un.org/documents/ga/res/38/a38r161.htm>.

. Report of the World Commission on Environment and Development: Our Common Future. 1987. Available at: $\overline{<h t t p: / / w w w . u n-d o c u m e n t s . n e t / w c e d-o c f . h t m>. ~}$

. International Merchandise Trade Statistics - Concepts and Definitions. Series F, n.52, Rev. 2 (United Nations publication, Sales n.E.98.XVII.16). UNITED NATIONS, 1998.

ŽIŽEK, Slavoj. The sublime object of ideology. London: Verso Books, 1989.

. Looking awry: an introduction to Jacques Lacan through popular culture. Cambridge, MA: MIT Press, 1991 a.

For they know not what they do: enjoyment as a political factor. London: Verso, 1991b. 